by 资

\title{
惯出口に大きい端板を付した長方形街突啧流に関する实駼“
}

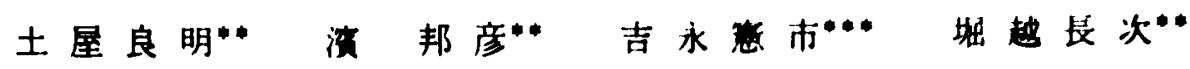

\section{Impingement of a Rectangular Jet with a Large End Plate at the Exit}

\author{
Yoshiaki TSUCHIYA, Kunihiko HAMA, Kenichi YOSHINAGA, \\ Choji HORIKOSHI
}

A rectangular jet from a long channel with a rectangular exit of an aspect ratio of five was vertically impinged on a flat plate. Taking the impingment distance as the parameter, the pattern of impingement flow, the velocity on the jet centerline and the pressure distribution on the flat plate were examined. Smoke of joss-sticks was used to observe the flow patterns. The pressure on the flat was measured thorough $0.5 \mathrm{~mm}$ diameter holes on the plate. Impingement distances were within 30 times the length of the short side of the rectangular exit.

The flow patterns on the impingement plate are found to change twice with increasing impingement distance. Some streamlines, not only on the large end plate but also on the impingement plate, form toward the jet exit at distant regions from both axes of the two plates in the case of small impingement distances. In addition, the spread of pressure distributions on the impingement plate is presented for different impingement distances.

\section{1. はじめに}

行突喷流は，とくに流体信号の発生に直接加わる 油空圧工学においてのみならず, 工嶪分野で広く応用 されている. たとえばノスル・フラッパー系変位セン サーの場合1，2)あるいは他の㧧流による流体力などの 利用に祭しては，物体との渻距崔が短い場合が多く， 流れは嚓出口付近の幾何学的形状の影震を受りる. 流

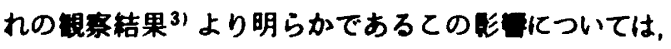

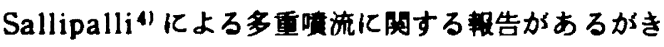
わめて少いようである.したかっって，最も典型的な喘 出口付近の形状として，德出口に大きい端板を付した

\footnotetext{
* 昭和61年 1 月13日 原稿受付

**信州大学工学部

***信州大学大学院
}

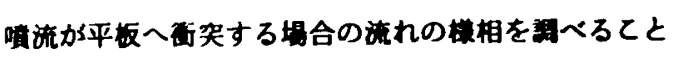

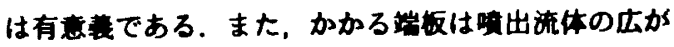
りを規制できるので、工莱用程での珢境保全の立场か らす重要であろう，一方，变位センサーの精度向上 ${ }^{51}$

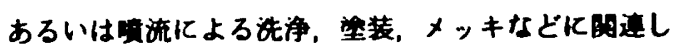
て重要である長方形出出口加の费流の画突について は，洪ら"，Kotanskyら

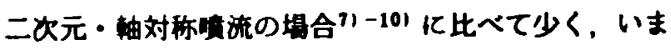
だ十分とは言えない。

本研究では，第一段階として，模比 5 の長方形淔 出口からの做流が比校的大きい平板へ垂直に籍突する

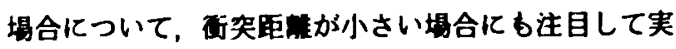

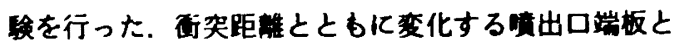
行突平板間の流九漛式，行突平板上の代力分布などに ついて調へた結果を㫰告する。なお，涨横比・形状の 自由噴流搪散様式への影雪が比较的少いてとが知られ 
ている゙11上流似長い平行部がある長方形賚出口を用 いた.

\section{2. おもな那号}

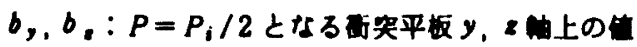

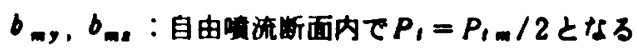

$y, z$ 伷上の位

h: 長方形出口短辺の長さ

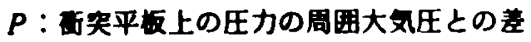

$U$ : 费流蚰方向速度

$\boldsymbol{w}$ : 長方形菑出口長刃の長さ

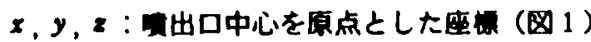

委字

：：等点における直

$m$ : 㓍流中心刺上における值

○：累出口における值

$t$ : 跉压

$s$ : 船压

\section{3. 実医装是およひ实酴方法}

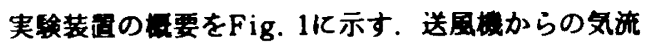
は、八ニカム、３呚の金敇によって風同1内で整流さ

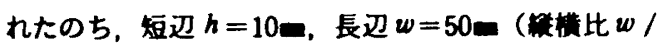
$h=5$ ）の長方形管 2 を通り，端板 3 と同一面にある

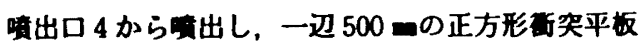

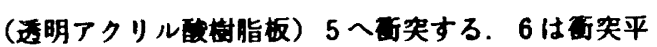
板上の中心蜼に治ってあけられた内径 0.5 =の圧力れ

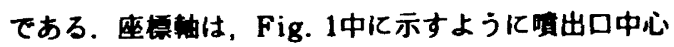

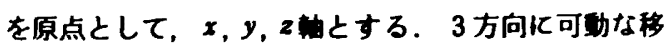

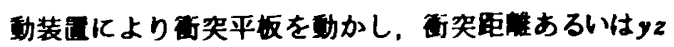
面内での圧力れの位西を㚆える.

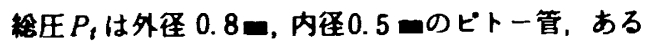
いは $0.8=$, 圧力れ径 0.3 صの内筒型ビト一管により,

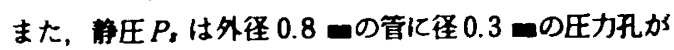

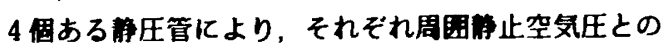
王力差として求めた．同様に平板上の圧力 $P$ も求める が，てれらの圧力は，㑯斜マノメーターにより测定， あるいは圧力変鱼器を通してペンレコーターで記觮さ

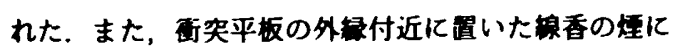
よって流れを可視化し，端板あるいは街㔖平坂上の流 れを透明な街㔖平板を透して下流側から锥察した。

哄出速度 $U_{0}$ は， $x_{1} / h=10$ 亿おいて設定したもの であり，したがって街㔖平板の影が嘖出口に及ぶ $x_{i} / h<3$ では，とくに記さない場合すとの設定值とは異 なる. おすに $U_{0}=22 \mathrm{~m} / \mathrm{s}, U_{0}$ とhに基つくレイノル ス数 $R_{\text {。 }}=13500$ について実飡した. なお，行突距教は $x_{1} / h \leq 30$ の筑围である。

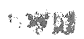

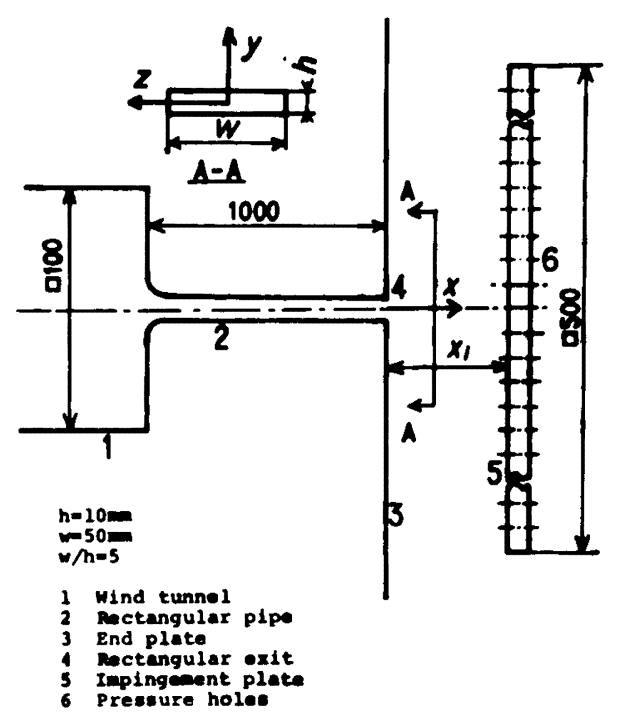

Fig. 1 Experimental apparatus

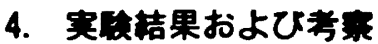

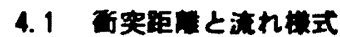

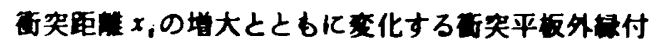

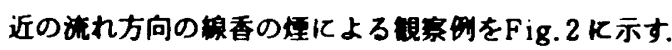

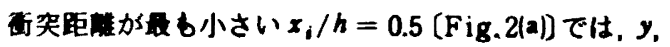

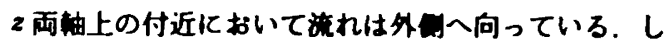
かしなからら， $x_{i} / h=0.7$ あたりを境にしてわすが

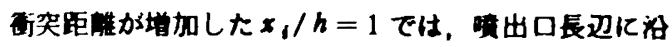
う方向である 2 此上てFig. 2 (b)に見るように惯出口人 向う流れへと変化する. 同倳な流九棁式は $x_{i} / h<6$

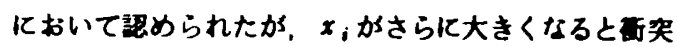

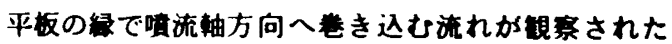
[Fig. 2 (c)). $x_{i} / h>18$ ではFig. 2 (d)に示すような 流九漛式へ変化する. Fig. 2 (b) (d)の各x2面の流れ の棈相を見れば，乙の面内での流れ柈式の変化通程か

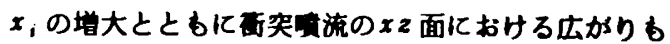
大きくなったてとに起因しているてと、また $\left.x_{i} / h\right\rangle$

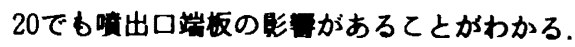

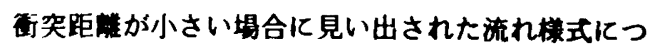

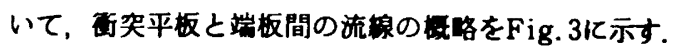
Fig. 3(a)は $y, z$ 両轴付近での流れが平板の外斯向う Fig. 2(a)の場合であり,Fig.3(b)，(c)はz 蚰付近の流 れが嘖流轴方向となるFig.2(b)の場合である。绵香の 煙の浮力の影副いくぶん認められており，定性的な 


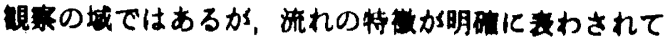

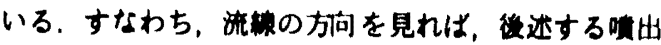

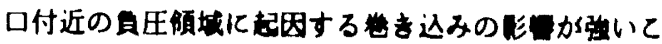

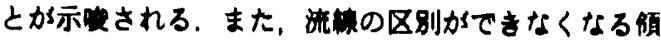

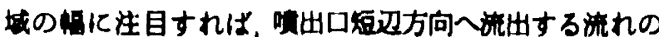

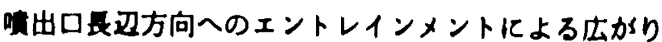
がう大をくはないととを示している。 なお， $x_{1} / h$

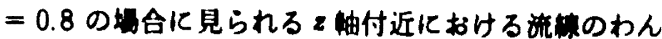

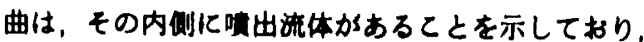

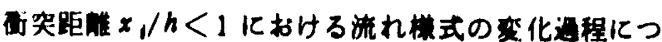

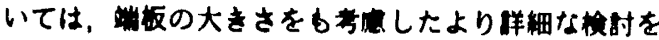
今後する必最か子ある。

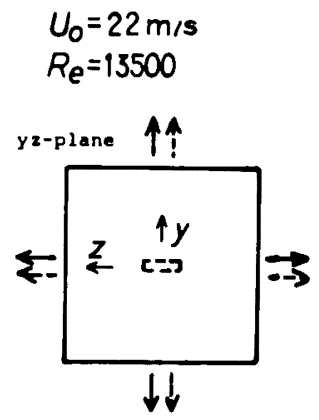

(a) $x_{i} / \mathrm{m}=0.5$

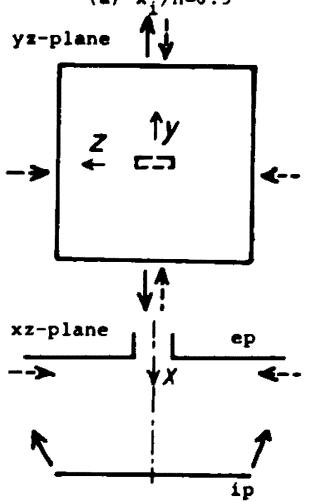

(c) $x_{i} / h=15$

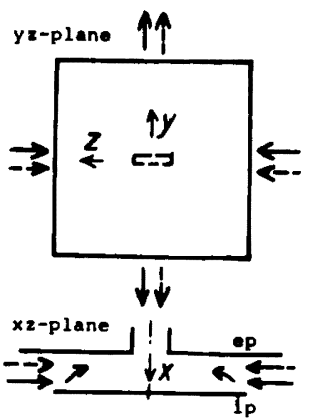

(b) $x_{1} / h=1,5$
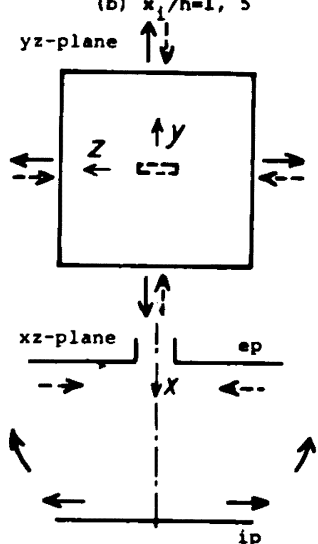

(d) $x_{i} / h=20$

ep:End plate 1p:Impingement plate

$-\rightarrow$ flow direction on the end plate

$\longrightarrow$ flow direction on the impingement plate

Fig. 2 Flow pattern

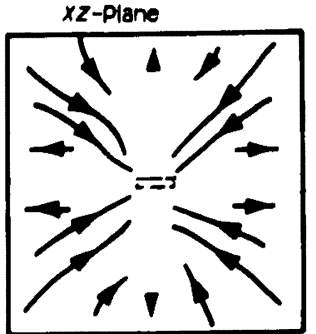

(a) $x_{1} / h=0.5$

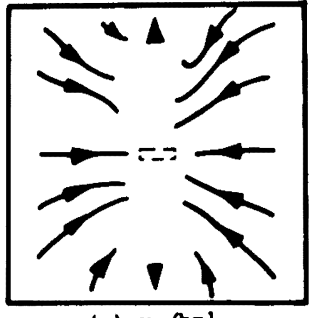

(c) $x_{1} / n=1$

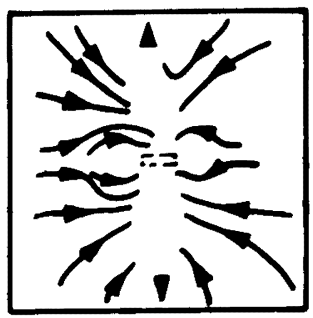

(b) $x_{1} / \mathrm{n}=0.8$

- - exit

- flor alrection

$U-22=/ s$

$R_{e-13500}$
Fig. 3 Sketch of streamline

\section{2 流中心上の压力分布}

流中心䌷上の速度 $U_{m}$ の分布をFig. 4 K，速度を

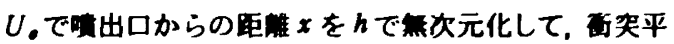
板の位国か $x_{i} / h=0.5,1 ， 5 ， 10,20,30$ の姆合飞つ いて示す. $x_{i} / h \geq 5$ 亿おいては，二次元・恓称

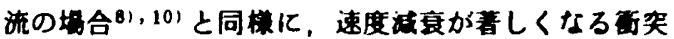

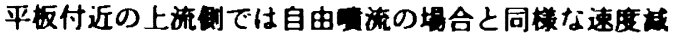
衰を示している。

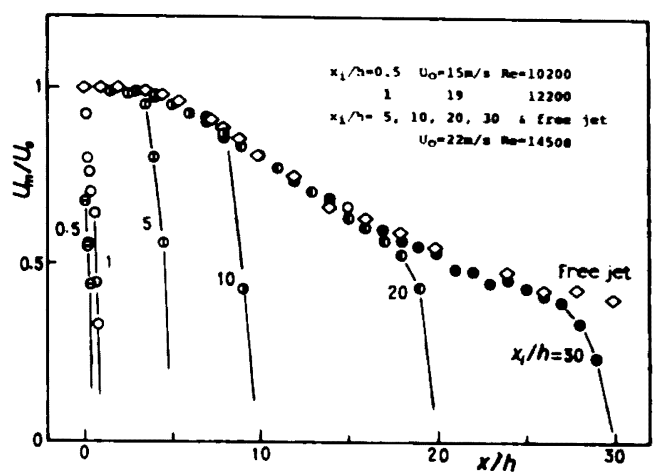

Fig. 4 Centerline velocity 


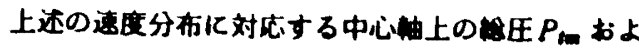

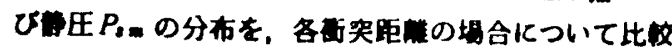

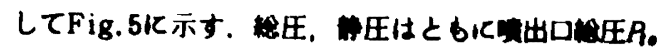

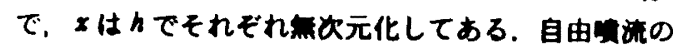

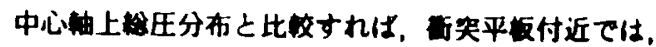

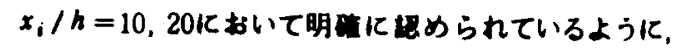

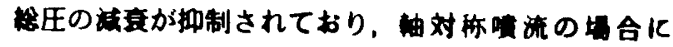

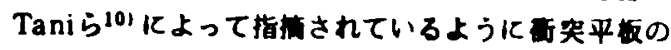

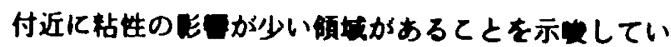

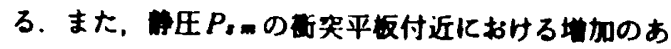

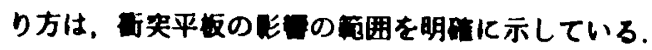

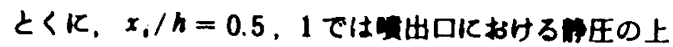

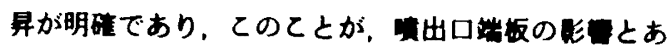
いまって，Fig.2(a)の流れ楼式加らFig. 2(b)のそれへ

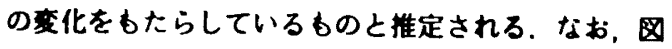
示はしないが，てれらの城合には先きに述へた没定值 より出口秢压も大きくなっている。

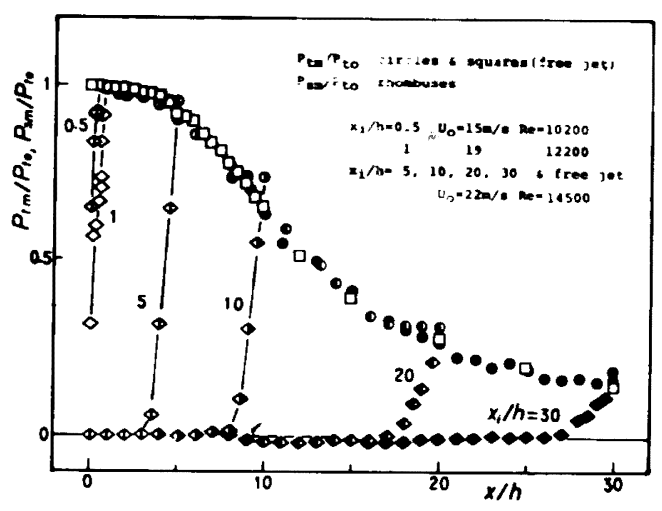

Fig. 5 Centerline total- and static-pressures

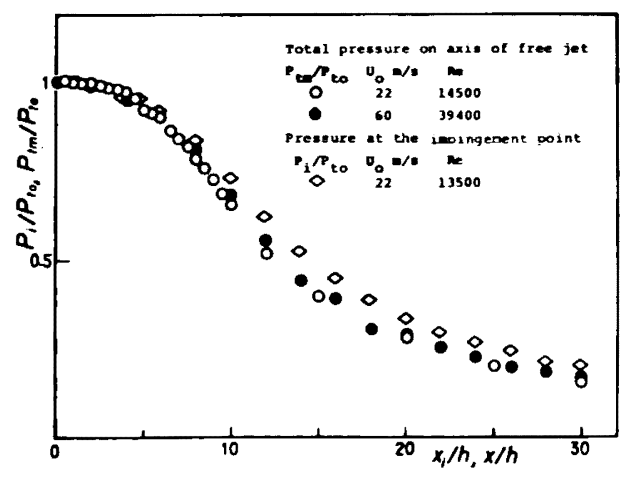

Fig. 6 Pressure at impingement point

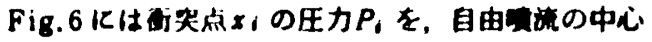

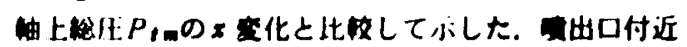

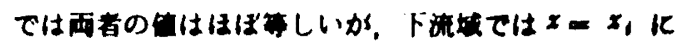

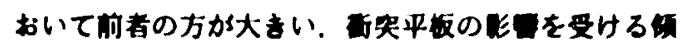

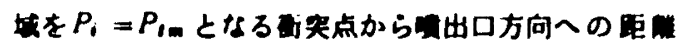

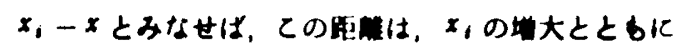
大きくなる烟局がうかがる。

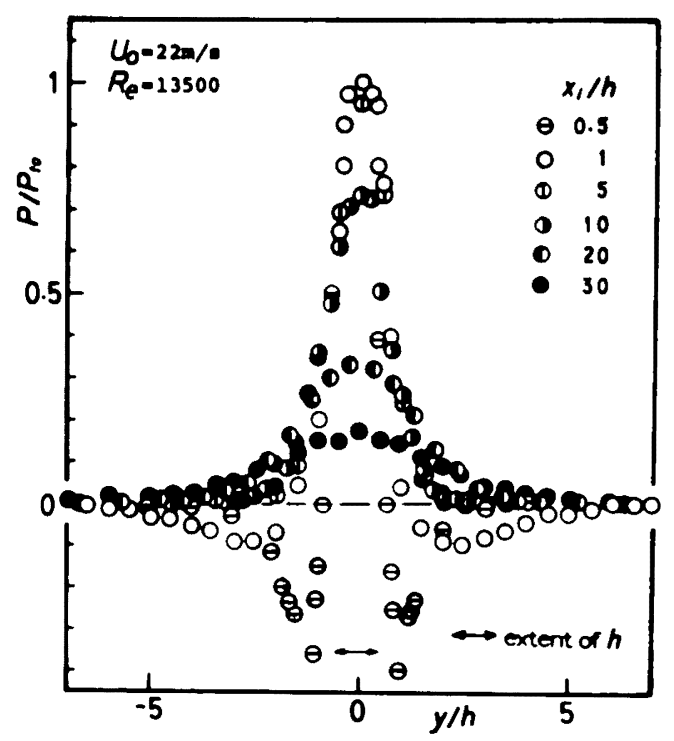

(a) along $y$

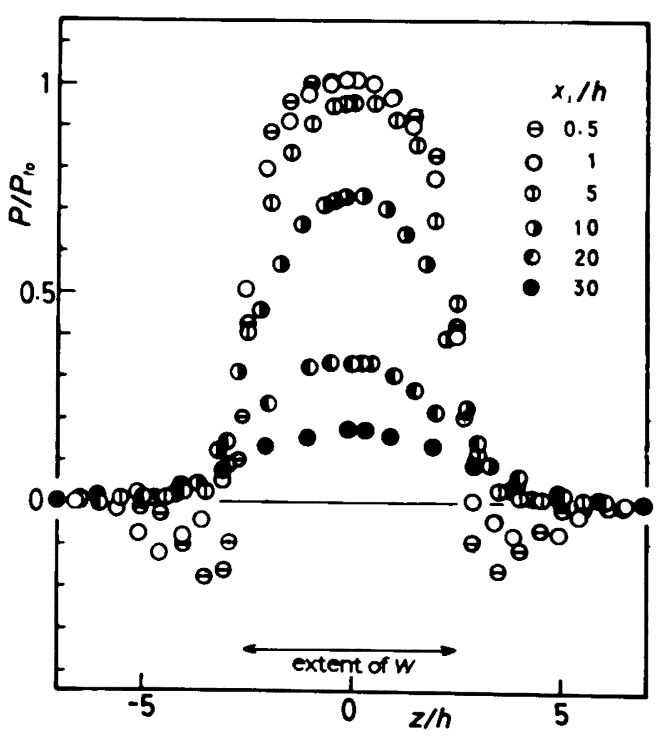

(b) along $z$

Fig. 7 Pressure on impingement plate 


\section{3 行笑平板上の圷力分布}

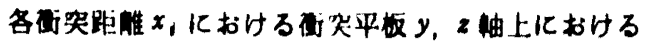

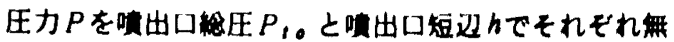
次元化してFig. 7 (a)，(b)/示す， $x_{i} / h=0.5,1$ て 明磼化晛われている見圧領城は， $x_{1} / h \geq 5$ でははと んどはめられない.

行笑平板上の压力分布の佉がりを $P=P_{1} / 2$ となる $y ， z$ 伷上の点を $b, b$ ，とし，自由啫流の断面内で総 压が $P_{1} m / 2$ となるをれらを $b_{m y}, b_{m}$ ，とした半值压 力㬈を，対比してFig.8亿示す，画者の半倠愊のx，

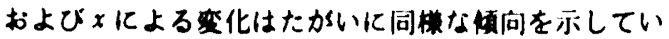

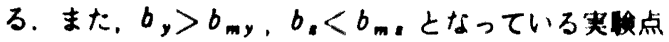
は，渞奖啫流加平板上で主としてy妯方向人流出して いるとと (Fig.2(b)，(c)) を反映しているbのと考え られる.

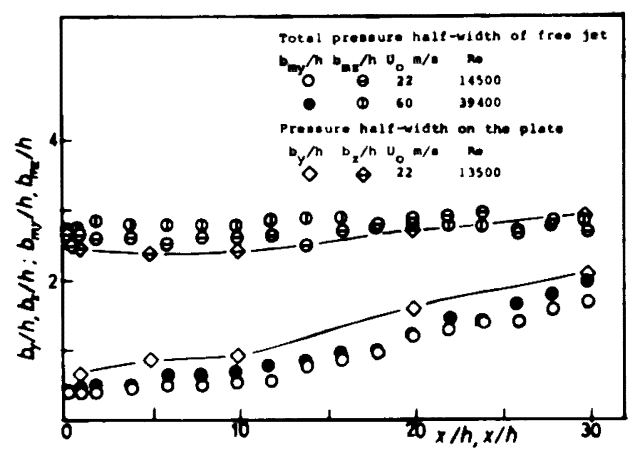

Fig. 8 Pressure half-width

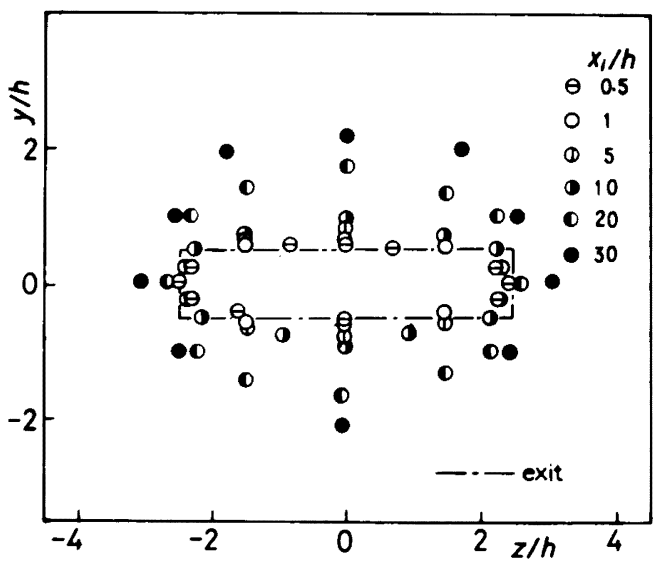

Fig. 9 Controur plots of pressure half-value $\left(P=P_{i} / 2\right)$ on impingement plate

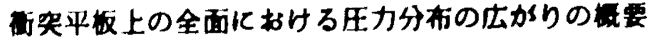
を示すために， $P=P_{1} / 2$ となる平坂上の点（半很 力点）を求めFig.9亿示す，広加りの分布形は，醉乫

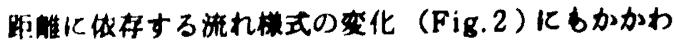

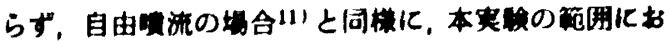
いてはy，2両妯をそれそれれ長油，哣㽘とするだ円で近 似ですもうである。

Fig.10には，笑点圧力で第次元化した平板上の代

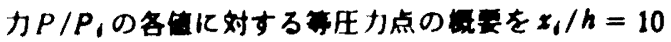

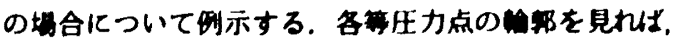

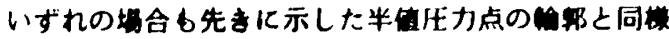
に，压力分布形が゙円形で近似されるととを示してい 3.

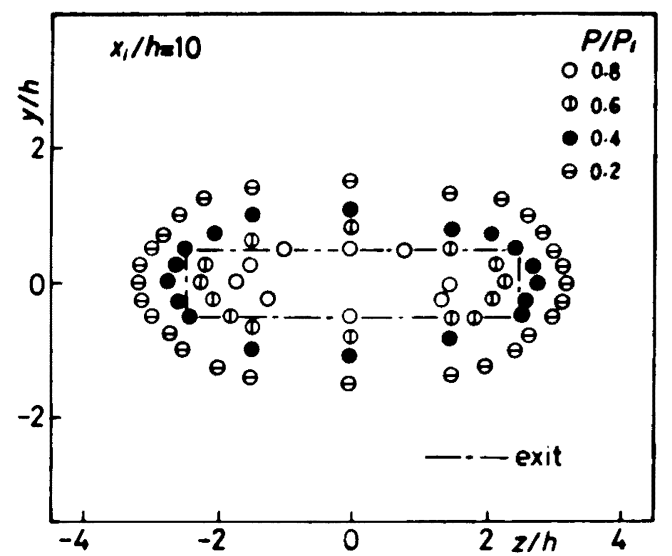

Fig. 10 Contour plots of pressure on impingement plate

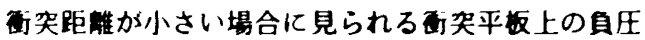

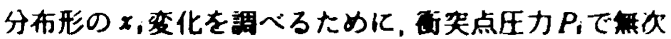
元化した箸突平板 $y ， z$ 軸上の圧力分布をFig.11(a)， (b)にそれぞれ示す．貝圧分布が明磪な $x_{i} / h=0.5$ ， 1では，y轴上におりる負圧が軸上のそれよりも大 きい， $x_{1}$ の增大ととも的軸上の頁圧の最大值は小さ

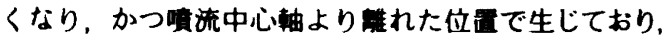
$x_{i} / h \geq 3$ では明磪な自圧領域は消诚している。

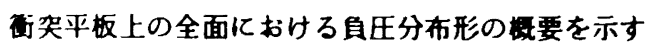
ために， $x_{i} / h=0.5,1$ の場合について $P / P_{i}=0$, 一 0.1 となる点を求めた結果を，それそれFig. 12 (a),

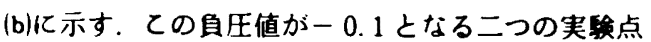
$(O, \ominus)$ の間の領域に注目すれば， $\boldsymbol{z}$ 轴上付近にお

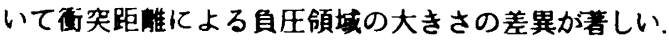
このととは， $x_{i} / h=0.5 ， 1$ 亿おいて $z$ 軸上付近の 流れ様式がたがいに異なっているてと(Fig.2(a),(b)) と関連があるものと推定される. 
Fig.13には， $x_{i} / h=1$ の场合について，䀧なる

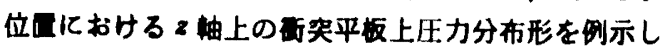

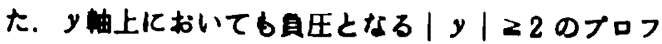

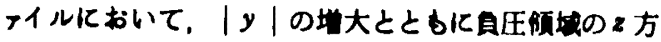

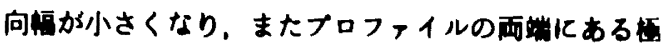

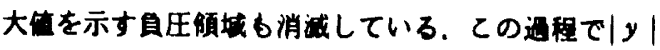

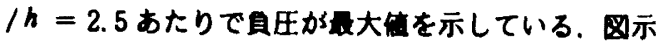

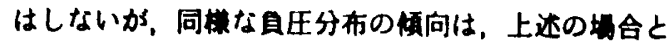

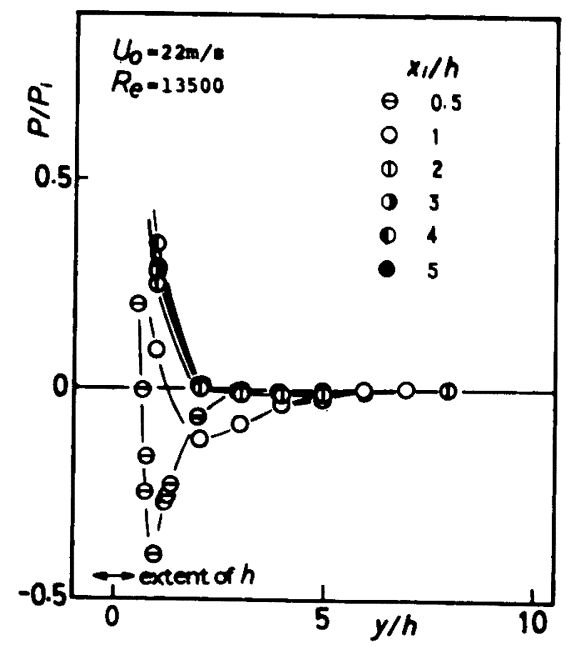

(a) along $y$

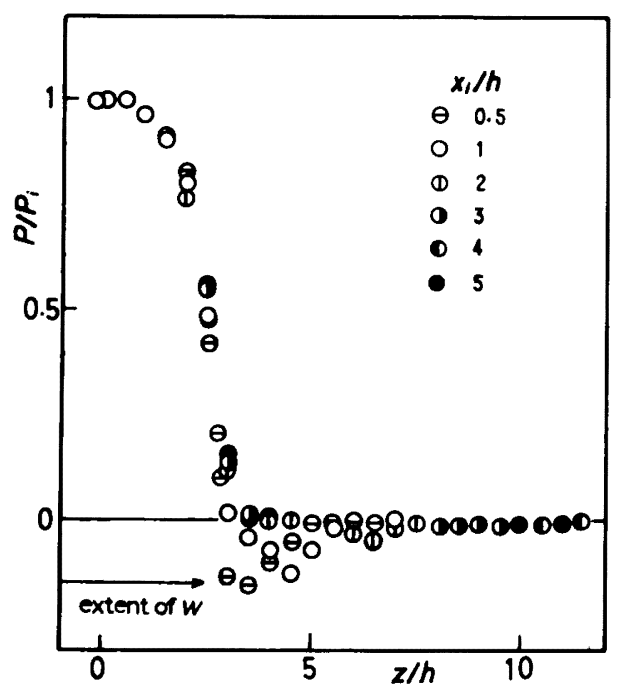

(b) along 2

Fig. 11 Negative pressure on impingement plate

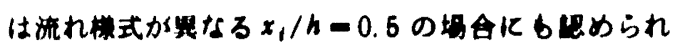

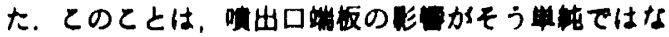
いてとを示眼している。したかっって，てれまで明ら

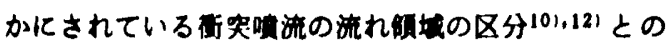

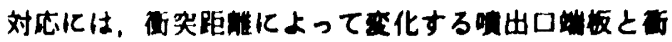

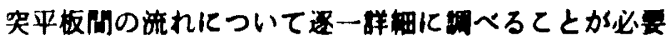
であり、今後の四である.

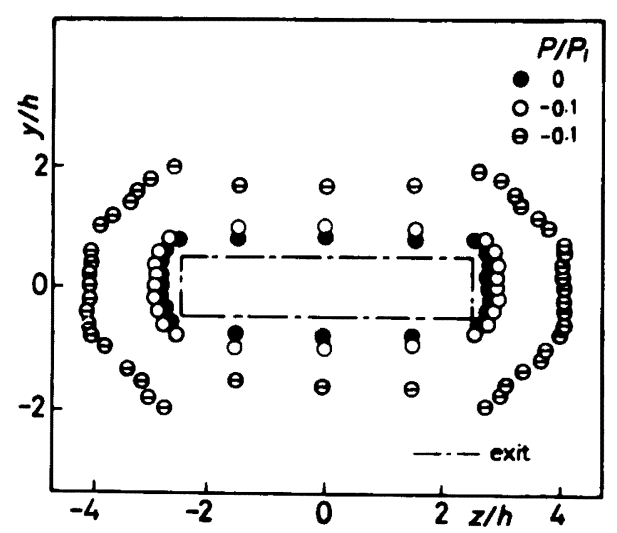

(a) $\mathrm{x}_{\mathrm{i}} / \mathrm{h}=0.5$

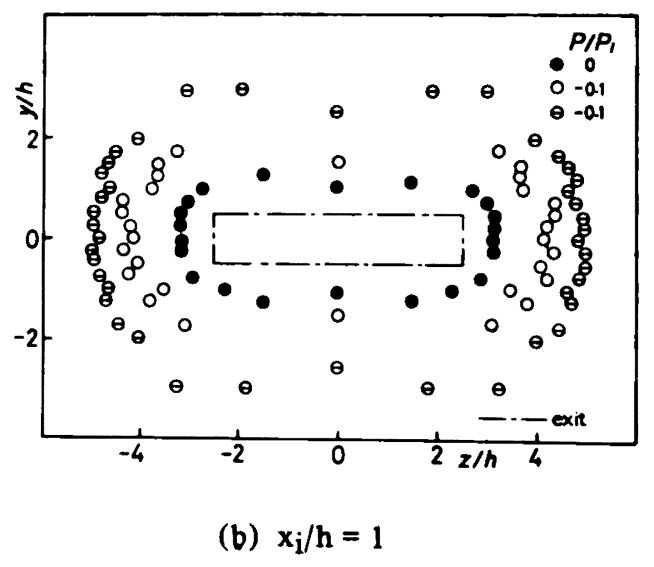

Fig. 12 Contour plots of negative pressure 


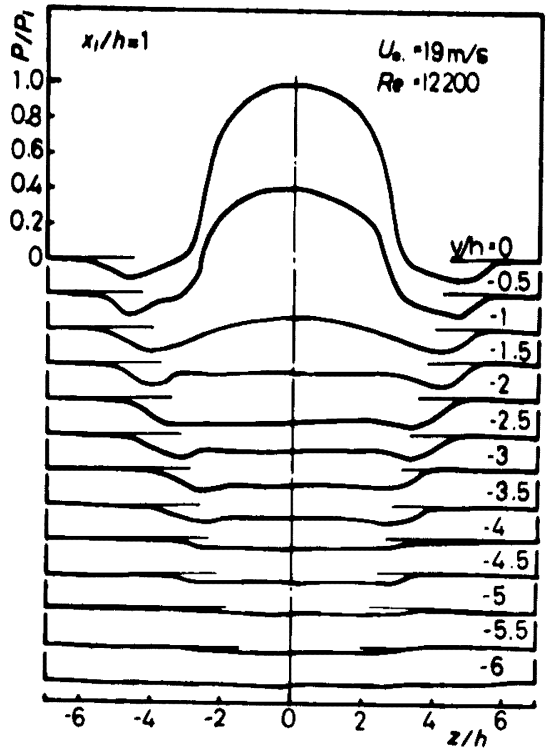

Fig. 13 Pressure profile on impingement plate at different transverse locations

\section{5. 結 咅}

喷出口に端板がある維棤比 5 の艮方形管から㖵出し， 平板へ嫖突する喷流について行った実段結果より，次 のととか明らかになった。

(1) 衡乫平板上で，y蚰方向へは常に流出するか， $z$ 妯付近においては，行㔖距離 $x_{i}$ ととるに流九の方向か 变化する.すすわち， $x_{i} / h=0.5$ では $y$ 蚰上と同様 に平板䜌より流出しているか， $x_{i} / h=0.8$ では逆に 平板緑において流入している. この頓向は $x_{1} / h=5$

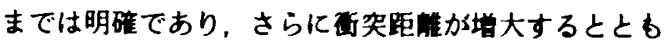
に再び平板編より流出する傾向がしだいに明確になる。 (2) $x_{i} / h \leq 5$ の衙乫距嚾汃小さい场合において，喷 出口端板と街突平板間の流れに啫出口へ向かう明確な 流線があるととを見い出した．乙のととが，嘪出口付 近に形成される自圧領城への巻き込みあるいはエント レインメントに起因しているてとが示㖪された。

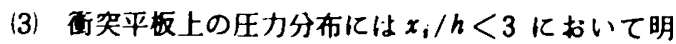
磼な員圧領域がある。負圧分布に求りる $y ， z$ 両軸上 の㖤小値は $x_{i}$ の增大とともにすみやかに小さくなり， かつ喷流中心軸より雖れた位珇で生ずるようになる。

(4) 街乫平板上の圧力分布の広がり之自由喷流断面の 総圧分布のそれとは， $y, z$ 両軸上の広がりにいくぶ ん差異があるあのの，ほぼ同様な煩向を示す。

以上のように，大きい噴出口端板之衙㔖平板を用い た最も典型的な場合についての基本的大要か得られた。 流れ場についての詳細な測定，また，長方形嗔出口の

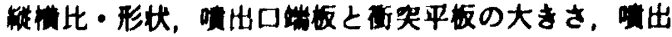

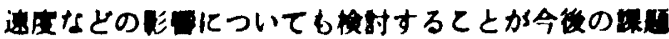

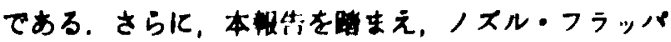

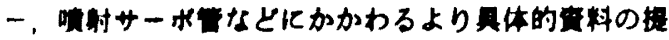
肇を行うこととしたい。

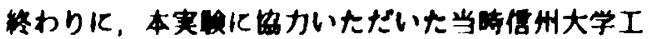

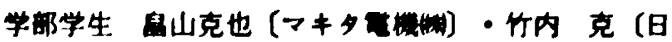

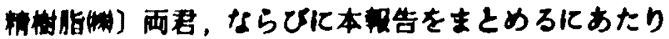
有益な时端をいただいた岡山大学 和田力数报に く蜠いたします。

\section{- 3 女 1}

1) 舴木: フルイディクス技得の体系化(6) フルイデ イク「变位センサ」, 油任と空爻圧，16-4，41 /50 (昭60).

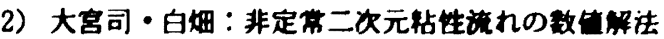

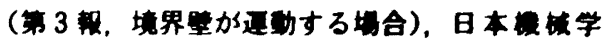
会镜文临，43-365，159/166(昭52).

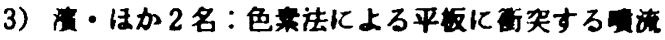
の流九模式の覞察，油压と空匃厈，16-7,44/53 (昭60).

4) W.R. Saripalli: Visualization of Multijet Impingement Flow, AIAA J., 21-4, 483/484 (1983).

5）原田・尾崎：流子工学, 35, 普是 (昭49).

6).D.R. Kotansky and L.W. Glaze: Impingement of Rectangular Jets on a Ground Plane, AIAA J., 20-5, 585/586 (1982).

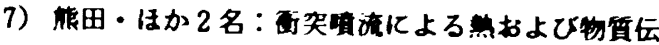
逢について，日本機柍学会范，76-655，822/830 (昭48).

8) E. Gutmark・はか2名：The Plane Turbulent Impinging Jet, J. Fluid Mech., 88-4, 737/756 (1978).

9）山田・はか3名：〈さひ面の二次元页架晴流に関

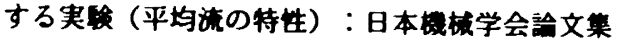

(B 編)，51-470，3297 / 3302 (昭60).

10) I. Tani and Y. Komatsu: Impingement of a Round Jet on a Flat Surface, Proceedings of the Eleventh International Congress of Applied Mechanics, Münich, 672/676 (1964).

11）土屋・ほ加3名：長方形聩流の拡散に威する研究 （第 2 報，平均速度搪散におよぼす啫出口形状の 影霖)，日本機械学会詥文集（B 編），51-461， 85 / 94 (昭60).

12) N. Rajaratnam: Turbulent Jets, 231/234, Elsevier (1976). 